\title{
Lineage Empowerment as Community Governance Model in Response to the Covid-19 Outbreak in Pasia Laweh Village
}

\author{
Syamsurizaldi ${ }^{*}$, Annisa Aulia Putri ${ }^{2}$, Miftahul Viona Sari ${ }^{3}$, M. Surya Ali \\ Dharma $^{4}$, Willy Silfiana ${ }^{5}$ \\ ${ }^{1}$ Lecture Departement of Public Administration Andalas University \\ ${ }^{2}$ Student Magister of Public Administration Andalas University \\ ${ }^{3}$ Student Magister of Public Administration Andalas University \\ ${ }^{4}$ Student Magister of Public Administration Andalas University \\ ${ }^{5}$ Student Departement of Public Administration Andalas University \\ *Syamsurizaldi. Email: syamsurizaldi@soc.unand.ac.id
}

\begin{abstract}
Kaum (lineage) are one of the three forms of kinship groups in Minangkabau society. Kaum (lineage) is a group of several paruik (sub lineage), and suku (clan) is a group of several clans and the nagari consists of at least four tribes. paruik, kaum and suku in the community's life is still exist today. Government of Nagari Pasia Laweh, Agam Regency is the first village in West Sumatra Province to try to empower people in overcoming the Covid19 outbreak which is thought to be in line with the implementation of the community governance model in public administration studies. This article aims to describe how the lineage empowerment as a model for community governance in overcoming Covid-19. The research method used is qualitative with descriptive analysis. The results showed that the prevention of the Covid-19 epidemic in Nagari Pasia Laweh was carried out by working together with the community in carrying out socialization, education and mitigation activities. To be able to prevent the spread of Covid-19, the existing people provide rumah gadang for isolation for migrants. The provision of isolation houses was also approved by Wali Nagari and KAN. Furthermore, the community also provides logistical needs for people who are being isolated. To be able to increase the empowerment of the people, Nagari Pasia Laweh also collaborated with the NDC of Andalas University in compiling the SOP for handling Covid-19 at the village level. Thus it can be concluded that the empowerment of the people in the response to Covid-19 in Nagari Pasia Laweh can be used as a role model for community governance in response to the Covid-19 outbreak at Village level.
\end{abstract}

Keywords: Lineage Empowering, Community Governance, Covid-19

\section{INTRODUCTION}

In the history of the development of public administration science, there has been a change from government to governance, which is driven by the fact that currently in managing the public sector government actors (state or government) are no longer the determinant, but have must share roles with non-government actors, namely the business (private) and the community (civil society). The term governance does not only mean governance as an activity, but also implies management, direction, development of governance and can also be interpreted as governance [1]. Koiman [2] defines governance as a process of socio-political interaction between government and society in various fields related to community interests and government intervention for these interests. Governance includes all mechanisms, processes and institutions by which citizens and community groups express their interests, exercise legal rights, fulfill obligations and bridge differences between them. In the history of past developments and trends in the future, the role of community (community governance) will increase in governance [3].

Law Number 6 of 2014 concerning Villages has brought changes to accelerate the development of villages and rural areas, where one of the fundamental changes is the recognition of the function of the village as a self-governing community in line with local self-government. This means that the existence of the village is not only an extension of the upper level government, but is also recognized as a community that has the authority to manage its own household affairs (autonomy) according to local values. Along with the development of social conditions in rural 
communities, of course this hope is not easy to realize, even though policies have provided the widest possible opportunity.

The existence of community governance, which legal experts call a legal community unit, has a long history in Europe and including Indonesia. In European countries there are various names of selfgoverning community, starting from the term community council in Spain, Commune in Italy, Parish in England [4]. Even a study in rural India illustrates the strong role of community governance as an institution that operates with social capital in collaborating to create active community participation [5]. One form of self-governing community that still exists in the government system in Indonesia to date is Nagari in Minangkabau [6]. The capacity of the nagari as a self-governing community can be seen from three things including: territorial, social and economic elements.

Several previous studies have shown that in the context of democratic life, the function of selfgoverning community in Nagari has not been realized as expected, due to the still strong role of upper-level government regulations in the form of Laws, Government Regulations, Ministerial Regulations and Regional Regulations governing village administration [6], [7]. The emergence of doubts and fears to act and innovate when something is not regulated (specifically) by a policy turns out to be a dilemma and problem in community-based development which should be independent in decision making [8]. The formation of a culture that is highly dependent on top-level regulations is one of the impacts of changing Nagari to Village Administration in the past, namely the change of Nagari (self-governing community) to Village (local state government) based on Law Number 5 of 1979 concerning Village Government which lasted for two decades in new order era [6].

In addition, in the current reformation era, it turns out that a large amount of village funds has been allocated since the enactment of the Village Law. On the one hand, it has had a positive impact, namely increasing resources to accelerate village development (nagari). But on the other hand, there is also a negative impact which is thought to weaken the function of the self-governing community. Research by Ekaputra et al. [9] found that the allocation of village funds had a negative impact on social capital variables, especially on the decreasing spirit of mutual cooperation. It turns out, economic improvement is very influential on the social capital of society which shifts the value of social relations into transactional relationships where everything is measured in material terms [9]. This was triggered by conditions at the beginning of the distribution of village funds (2015-2017), where their use was very dominant for the (physical) village infrastructure development where the administrative, planning, implementation and reporting processes were almost the same as the contractual project work system by the local government, thus reducing the motivation. to work together. Meanwhile, due to the large budget allocation for physical development, only a small portion of the budget was allocated for empowering the village community [10].

Efforts to strengthen Nagari as a selfgoverning community have been carried out by the West Sumatra Provincial Government by establishing Regional Regulation Number 7 of 2018 concerning Nagari, where the existence of village government including traditional village construction has been accommodated and strengthened, this is also in line with the mandate of the Village Law. However, until now the implementation of customary nagari as an institutional representation of the self-governing community has not progressed as expected.

Indonesia is currently facing the Corona Virus Disease 2019 (Covid-19) pandemic. This pandemic is spreading rapidly in various countries, and has been designated a global pandemic by WHO. Based on daily reports on July 17, 2020, the Covid-19 pandemic has plagued 216 countries with 13.3 million confirmed cases, and 580,045 deaths. Meanwhile, positive cases in Indonesia reached 81,668 , which makes Indonesia the country with the highest cases in Southeast Asia (covid19.go.id).

The addition of significant cases every day demands that the government be able to take emergency response steps in handling it. The government must be able to formulate a strategy to deal with this virus from the central to regional levels. The consequences of this pandemic are not only on the health sector, but also have an impact on the social and economic life of the community. Overcoming this pandemic requires activeness from the government and also the community. Therefore, a governance concept that involves the community actively is needed so that this pandemic can be overcome. The government can implement a selfgoverning community, where the community works together to handle covid-19. Self-Governing 
Community in handling Covid-19 has been implemented in Nagari Pasia Laweh, Palupuh District, Agam Regency. This Nagari provides 58 units of rumah gadang as a place for independent isolation of migrants returning to Nagari Pasia Laweh. In the case of isolation, the community works together at the community and nagari level in providing consumption during isolation. The initial phenomenon of Nagari Pasia Laweh in tackling the Covid-19 Nagari as a community-based service innovation is interesting to study further using a community governance model, in line with the function of the village as a self-governing community based on Law Number 6 of 2014 concerning Villages.

The approach used in this research is qualitative. According to Bodgan and Taylor, qualitative research is a research procedure that produces descriptive data in the form of written words from the behavior of the people being observed [16]. This type of research is descriptive analysis. The data used in this study are primary data and secondary data. This research was conducted in Nagari Pasia Laweh, Palupuah District, Agam Regency. The reason for choosing the location was because this village was a community-based pilot village for the prevention of Covid-19 in West Sumatra Province.

\section{COMMUNITY GOVERNANCE}

Community governance is one of the pillars or actors of governance, and many experts argue that community governance has the oldest history compared to government (state) and corporate governance (private) actors. According to Clarke \&
Stewart [11]community governance is a term used to describe decision-making processes that occur at an appropriate scale and are considered legitimate by the community. Therefore community governance can be understood as a special form of political governance (including governance) which may be at the highest level in democratization by empowering the public as a 'community' [12] or realizing local democratization of government [13]. Sudarmo [14] describes the capacity of community in governance as follows: "(1) the ability to organize themselves informally, (2) the willingness to learn from previous experiences and things that are not yet known to anticipate things to come, (3) work in a different time. clear and tangible through the network, (4) willingness to share roles among the diversity of actors / stakeholders as available human and non-human resources, and (5) the implementation of intelligence distribution to solve common problems, and this means demanding a willingness to share information and open communication which guarantees transparency, responsiveness and accountability to each other, and adaptation to uncertain and complex environmental situations".

The concept of community governance is also a concern of experts in examining the development of a governance perspective in public administration. For example, the model is offered as a continuum to measure theoretically intervention in community governance according to Totikidis, Amstrong \& Francis [8] as shown in Table

Table 1

Community Governance Model as a Continuum

\begin{tabular}{|c|c|c|}
\hline Community Leadership & Community Empowerment & Community Ownership \\
\hline $\begin{array}{l}\text { Reflects the concept of a } \\
\text { group of people and groups of } \\
\text { people working together to } \\
\text { achieve a common goal and } \\
\text { vision. }\end{array}$ & $\begin{array}{l}\text { Community empowerment, both } \\
\text { for people who have resources } \\
\text { and those who can access } \\
\text { resources. Resources needed to } \\
\text { meet basic needs (eg food, } \\
\text { shelter, income) up to higher } \\
\text { level needs (eg social } \\
\text { interaction, support for self- } \\
\text { development). It is clear that } \\
\text { there is a relationship between } \\
\text { economic and social capital. }\end{array}$ & $\begin{array}{l}\text { In this dimension, it is related to } \\
\text { the way a person is connected } \\
\text { to his community, so that he } \\
\text { feels belonging and wants to be } \\
\text { seen in his community. }\end{array}$ \\
\hline $\begin{array}{ll}\text { - } & \text { Share vision and } \\
\text { understanding; } \\
\text { - } & \text { Community participation; } \\
\text { - } & \text { Cooperative behavior } \\
\text { - } & \text { Community or community } \\
\text { advocacy. }\end{array}$ & $\begin{array}{l}\text { - } \\
\text { - } \\
\text { - } \\
\text { Dhare power; } \\
\text { making. } \\
\text { mation in decision } \\
\text { malesources; } \\
\end{array}$ & $\begin{array}{ll}- & \text { A sense of belonging; } \\
- & \text { Care } \\
- & \text { Has a bond in a place (area) } \\
\text { - } & \text { Value diversity }\end{array}$ \\
\hline
\end{tabular}


Source: Totikidis, Amstrong \& Francis (2005)

\section{Form of Covid-19 Control in Nagari Pasia Laweh}

Nagari Pasia Laweh is one of the Nagari in West Sumatra where was responsive in responding to the national disaster of the Covid-19 Pandemic. Wali Nagari Pasia Laweh as the Nagari Government Leader administratively has a very important role in managing the Covid-19 response. In dealing with Covid-19 Wali Nagari empowers human resources in Nagari Pasia Laweh itself. Nagari Pasia Laweh which has Nagari Density consisting of 122 Kaum 100 Niniak mamak, 52 Kampung, 7 Jorong, and 7 suku which are sufficient human capital to be empowered in overcoming the prevention and spread of the Covid-19 Pandemic. Based on 1) Decree of the Minister of Health Number HK.01.07 / MENKES / 260/2020 concerning the Stipulation of Large-Scale Social Restrictions in the Region of West Sumatra Province in the Context of Accelerating Handling of Corona Virus Disease 2019 (COVID-19), 2) West Sumatra Governor Regulation Number 20 of 2020 regarding Guidelines for Large-Scale Social
Restrictions in Handling Corona Virus Disease 2019 (Covid 19) in West Sumatra, and 3) Circular of the Village Minister Number 8 of 2020 Regarding Covid-19 Response Villages and Affirmation of Village Cash Work Intent, Nagari Pasia Laweh Government established a Task Force The Village Volunteer, chaired directly by the Wali Nagari and the Deputy Chair, is the Head of the Narrative Bamus. Meanwhile, the Volunteer Team members consist of institutions in the village as well as representatives of the people in the village.

The formation of the village volunteer team is carried out by means of deliberation, namely by inviting all elements in the village. Furthermore, the perception of the dangers of Covid-19 was carried out, then the volunteer team of Nagari Pasia Laweh was determined. The first form of activity carried out was a village meeting regarding the response to Covid-19. Deliberation is carried out by inviting the niniak mamak of each clan. The results of the meeting were in the form of activities that will be carried out to tackle Covid-19 as shown in Table 2.

Table 2.

Covid-19 Countermeasures Activities in Nagari Pasia Laweh

\begin{tabular}{|c|c|c|}
\hline No & Type of activity & Explanation \\
\hline 1 & $\begin{array}{l}\text { Provision of an officer post as well as a } \\
\text { Covid-19 data and information center }\end{array}$ & $\begin{array}{l}\text { Serves as a basecamp, and as a Covid- } 19 \text { center. Any data } \\
\text { related to Covid- } 19 \text { can be accessed at this post. This post is } \\
\text { the main activity place for the Covid- } 19 \text { volunteer team. }\end{array}$ \\
\hline 2 & $\begin{array}{l}\text { survey about public understanding of } \\
\text { Covid-19 }\end{array}$ & $\begin{array}{l}\text { Distributing questionnaires to the public. The survey results } \\
\text { were used to design outreach activities to be carried out by the } \\
\text { village volunteer team. }\end{array}$ \\
\hline 3 & Spraying antiseptic into people's homes & done by a team of volunteers, working with the people \\
\hline 4 & Make Covid-19 prone map & serves to register the community, and create a map \\
\hline 5 & $\begin{array}{l}\text { Body temperature measurement and free } \\
\text { mask stalls on the market }\end{array}$ & Provision of free masks for the public in the market \\
\hline 6 & $\begin{array}{l}\text { Provision of rumah gadang as the } \\
\text { isolation of the people }\end{array}$ & $\begin{array}{l}\text { The Rumah Gadang, which is the place for isolation for the } \\
\text { people in the village, is } 122 \text { houses }\end{array}$ \\
\hline 7 & $\begin{array}{l}\text { Provision of logistical needs for people } \\
\text { who carry out isolation }\end{array}$ & Provided by each clan \\
\hline 8 & $\begin{array}{l}\text { Writing competition on the theme of } \\
\text { Covid-19 }\end{array}$ & $\begin{array}{l}\text { Followed by the general public, students and university } \\
\text { students }\end{array}$ \\
\hline
\end{tabular}

\section{MODEL OF EMPOWERING PEOPLE IN THE RESPONSE TO COVID-19}

Nagari Pasia Laweh, which is located on the Bukittinggi-Medan highway, has recently received a lot of attention because of its Wali Nagari's breakthrough regarding the community-based handling of Covid-19. This breakthrough also received a positive response from many parties, one of which was from the Agam Regency Government. This breakthrough also made Nagari Pasia Laweh become one of the disaster resilient villages in Agam Regency. Not only in the implementation of covid countermeasures, but many things in Nagari Pasia Laweh empower people in handling them, such as forest utilization which is also community-based. So that the 
community-based covid response is not something new for the people of Nagari Pasia Laweh. The model of empowering the people in the response to
Covid-19 in Nagari Pasia Laweh is described in table 3 .

Table 3.

Model of Empowering People in The Response to Covid-19 di Nagari Pasia Laweh

\begin{tabular}{|c|c|c|}
\hline Kepemimpinan Komunitas & Pemberdayaan Komunitas & $\begin{array}{c}\text { Kepemilikan } \\
\text { Komunitas }\end{array}$ \\
\hline $\begin{array}{l}\text { Vision: "Realizing Nagari } \\
\text { Maju Based on Local } \\
\text { Wisdom" } \\
\text { This vision is translated into } \\
\text { the response to Covid-19: a } \\
\text { people-based Covid-19 } \\
\text { response }\end{array}$ & $\begin{array}{l}\text { The village government and the } \\
\text { people share a role in response } \\
\text { to Covid-19 }\end{array}$ & $\begin{array}{l}\text { The motto that is always used: } \\
\text { sahino samalu }\end{array}$ \\
\hline $\begin{array}{l}\text { Decisions on activities to be } \\
\text { carried out are taken at the } \\
\text { time of deliberation, with the } \\
\text { consent of the community }\end{array}$ & $\begin{array}{l}\text { niniak mamak plays an } \\
\text { important role in mobilizing } \\
\text { resources. }\end{array}$ & $\begin{array}{l}\text { There is a feeling of shame and } \\
\text { exclusion when people are not } \\
\text { involved in the Covid-19 } \\
\text { response in the village }\end{array}$ \\
\hline $\begin{array}{l}\text { Volunteer members: delegates } \\
\text { of the people, responsible to } \\
\text { the niniak mamak clan. }\end{array}$ & $\begin{array}{l}\text { The village government plays } \\
\text { an important role in facilitating } \\
\text { the Covid- } 19 \text { response activities } \\
\text { carried out by the people }\end{array}$ & $\begin{array}{l}\text { People outside the nagari will } \\
\text { malakok to the people in the } \\
\text { nagari, and are regulated based } \\
\text { on customary provisions }\end{array}$ \\
\hline $\begin{array}{l}\text { Niniak mamak collaborates } \\
\text { with the wali nagari to guide } \\
\text { the people who become } \\
\text { representatives of the } \\
\text { volunteer team }\end{array}$ & $\begin{array}{l}\text { The people are more dominant } \\
\text { in carrying out Covid- } 19 \\
\text { countermeasures, and the } \\
\text { village government is providing } \\
\text { guidance and collaborating with } \\
\text { niniak mamak. }\end{array}$ & $\begin{array}{l}\text { Outsiders who are Malakok get } \\
\text { the same treatment as the local } \\
\text { community, and are actively } \\
\text { involved in the response to } \\
\text { Covid-19 }\end{array}$ \\
\hline
\end{tabular}

\section{CONCLUSION}

The response to the Covid-19 pandemic must be carried out by involving all existing elements. In Nagari Pasia Laweh, there were several activities carried out, namely providing a covid-19 officer post and data and information center, conducting surveys about public understanding of Covid-19, spraying antiseptic to residents' homes, making Covid-19 prone maps , measuring body temperature and free mask stalls on the market, providing rumah gadang as isolation for the people, providing logistical needs for people who isolate people, holding writing competitions with the theme of Covid-19. The response to Covid-19 in Nagari Pasia Laweh was carried out by empowering the people. The model of empowering the people in overcoming Covid-19 in Nagari Pasia Laweh is to equate the vision and understanding between the wali nagari as government leaders and niniak mamak as community leaders. Furthermore, Niniak Mamak will coordinate the people to participate in the response to Covid. decisions are taken together, and the people who determine the activities can be carried out. Furthermore, the implementation of Covid-19 countermeasures activities is left to the people, accompanied by the village government. The high sense of belonging in
Nagari is in accordance with the existing motto in Nagari Pasia Laweh, namely Sahino Samalu.

\section{ACKNOWLEDGMENT}

Thank you to Faculty of Social and Political Scince, Andalas University for funding research activities through contract letters Number: 01/PL/SPK/PNP/FISIP-UNAND/2020 on September 1, 2020.

\section{REFERENCES}

[1] Sedarmayanti, Sumber Daya Manusia dan Produktivitas Kerja. Bandung: Mandar Maju, 2004.

[2] J. Koiman, Governing in Governance. Sage Publication, 2008.

[3] Kushandajani, “Aplikasi Community Governance Dalam Pengelolaan Program Penanggulangan Kemiskinan," Polit. J. Ilmu Polit., vol. 4, no. 1, pp. 41-48, 2014.

[4] M. Natsir, "Surau dan Upaya Mewujudkan Self Governing Community di Sumatera Barat," in Kompetensi Pendamping Pembangunan Desa, p. 135.

[5] A. Krishna, "Enhancing political 
participation in democracies: What is the role of social capital?," Comp. Polit. Stud., vol. 35, no. 4, pp. 437-460, 2002.

[6] Amailatulwalidain, "DEMOKRASI LOKAL DI SUMATERA BARAT Memahami Pendekatan 'Self Governing Community' Pada Sistem Pemerintahan Nagari Modern di Minangkabau," J. Pemerintah. Dan Polit., vol. 2, no. 1, pp. 18, 2016.

[7] Masyitah, "VILLAGE GOVERNANCE : Village Democracy in the Frame of Self Governing Community and Local Self Government," Meraja J., vol. 2, no. 3, pp. 85-99, 2019.

[8] V. Totikidis, A. F. . Armstrong, and R. D. Francis, "The concept of community governance: a preliminary review," GovNet Conf., no. January, p. 20, 2005.

[9] E. Ekaputra et al., Data dan Informasi ; Manfaat dana desa di Provinsi Sumatera Barat. 2018.
[10] Syamsurizaldi, A. A. Putri, and S. Antoni, "MODEL COLLABORATIVE GOVERNANCE PADA NAGARI RANCAK DI PROVINSI SUMATERA BARAT," J. Pembang. Nagari, no. 1, pp. 99-121, 2019.

[11] M. Clarke and J. Stewart, Citizens and Local Democracy: Empowerment A Theme for the 1990s. Luton, 1992.

[12] M. Clarke and J. Stewart, "The local authority and the new community governance," Local Gov. Stud., vol. 20, no. 2, pp. 163-176, 1994.

[13] M. Clarke and J. Stewart, Handling the Wicked Issues: A Challange for GOvernment. Birmingham: University of Birmingham, 1997.

[14] Sudarmo, "TATA KELOLA KOMUNITAS TERHADAP PROSTITUSI: REHABILITASI SOSIAL BAGI PEKERJA SEKS MELALUI MODAL SOSIAL," J. Borneo Adm., vol. 15, no. 2, pp. 117-136, 2019. 